УДК 614.7: 616-053.2

\title{
HYGIENIC ENVIRONMENTAL ASSESSMENT AND HEALTH OF CHILDREN IN PENZA
}

\author{
Yu.V. Korochkina ${ }^{1}$, M.V. Perekusikhin ${ }^{2}$, V.V. Vasilyev ${ }^{3,4}$, G.V. Panteleev ${ }^{1}$ \\ ${ }^{1}$ FBHI "Center of Hygiene and Epidemiology in the Penza Region”, Russian Federation, Penza, Building 3, \\ Marshala Krylova St., 440036 \\ ${ }^{2}$ Directorate of Rospotrebnadzor in the Penza Region, Russian Federation, Penza, 36 Lermontova St., 440036 \\ ${ }^{3}$ FBEI HPE "Penza State University”, Russian Federation, Penza, 40 Krasnaya St., 440036 \\ ${ }^{4}$ SBSI "Penza Regional Clinical Hospital named after N.N. Burdenko", Russian Federation, 28 Lermontova St., 440036
}

Assessment of the carcinogenic risk from air pollution, the chemical composition of the drinking water and the content of contaminants in food showed that the total cancer risk for both inhalation and oral routes of administering priority pollutants and contaminants into the body of Penza children and adolescents complies with the maximum permissible level. The greatest risk of non-carcinogenic impact associated with air pollution is generated in respect of the respiratory system, eyes and immune system. The maximum hazard indices associated with the consumption of drinking water, are set for blood, hormone system and kidneys. The risk of negative impacts associated with the receipt of food contaminants is observed in respect of the hematopoietic and cardiovascular systems. Application of risk assessment methodology to study the effects of chemicals polluting the environment on health has allowed to justify preventive measures aimed at reducing the risk to the health of children and adolescents, as well as increased monitoring researches of environmental objects to isolate areas of high risk to children's health.

Key words: risk assessment, carcinogenic and non-carcinogenic risks, air, drinking water, food, children.

Thematic Justification. Industrial growth does not always mean improved environmental quality and, as a consequence, the level of protection of the population and the environment does not reach the point when there are no impermissible risks associated with exposure to hazardous chemical and biological factors $[1,4,6,8]$. The chemical pollution of the air, drinking water and soil cause $11.4 \%$ of deaths in the area, and $12.5 \%$ of illnesses, on average. In the last decade, more and more attention in the assessment of environmental impact on public health is given to the calculation of risk and damage to health for the purposes of management decisions [7, 9, 11-15]. The methodology of risk assessment is particularly important in the determination of the health effects of long-term exposure of children to chemical substances in the concentrations below the regulated level. It was demonstrated that a chemical substance in the concentration below the regulated level can still have a rather high impact on child health [2-4]. For this reason, the probability of negative effects caused by environmental contaminants, determined by the level of risk to health, can be used to validate the need for preventative activities in specific regions and towns [10,9].

At year-end 2014, Penza Region was referred to the group of regions with relatively high indicators of sanitary-epidemiological well-being [6]. However hazardous environmental factors in the region are still causing health problems. Consequently, further analysis and restorative actions are needed $[4,5]$.

Purpose of the study is to analyze the impact of the environment on child health in Penza with the application of risk assessment methodology to validate the action plan aimed to reduce the health risks faced by children and teenagers.

Materials and methods. The publication presents the analysis of the data provided by the regional information fund on the results of the sociohygienic monitoring conducted in 2007-2014 in Penza. The results of sanitary-chemical laboratory studies of drinking water (83352 studies), atmospheric air (55833 studies), soil (7513 studies), and food raw materials and food products (4507 samples) were statistically processed. To select the necessary information that would help determine

(C) Korochkina Yu.V., Perekusikhin M.V., Vasilyev V.V., Panteleev G.V., 2015

Korochkina Yulia Valentinovna - Deputy Chief Medical Officer for laboratory support, metrology, standardization and accreditation (e-mail: korochkina@cge58.ru; tel. (8412) 54-85-94).

Perekusikhin Mikhail Vladimirovich - Head (e-mail: sanepid@ sura.ru; tel. (8412) 55-26-06).

Vasilyev Valery Valentinovich - Doctor of Medicine, Professor, Department of Hygiene and Public Health and Healthcare, Doctor-methodologist of Organizational and Methodical Department (e-mail: vvv1755@ yandex.ru; tel. (8412) 5917-46).

Panteleev Gennadv Valentinovich - Chief Medical Officer (e-mail: panteleev@ cge58.ru: tel. (8412) 54-85-94) 
the major environmental factors contributing to the health problems, we used the approach based on the selection of the indicators of actual and potential pollution including the leading pollutants and the pollution impact based on which we selected the health indicators.

Assessment of the risks associated with chronic chemical exposure was conducted following Guidelines P 2.1.10.1920-04 "Assessment of the health risks associated with chemical environmental pollutants" and guidelines MU 2.3.7.2519-09 "Determination of public exposure and risk assessment of chemical contaminants in food products". To calculate the level of exposure, we used median and $90^{\text {th }}$ percentile of the chemical content in food products.

To determine the impact of air pollutants on public health, we calculated the risk of potential carcinogenic and non-cancer effects. Non-cancer risk was characterized by hazard quotient (HQ) and hazard index (HI). If risk exceeded 1 in terms of any of these indicators, it was considered impermissible. Carcinogenic risk was expressed through the probability of an oncological disease throughout life. The substances that were used to identify risk included formaldehyde and lead.

Results and discussion. The following chemical substances are considered to be the biggest air pollutants emitted by industrial enterprises in Penza, according to long-term studies: particulate substances, sulfur dioxide, nitrogen dioxide, carbon monoxide, formaldehyde, and lead. According to the results of a monitoring study carried out in 2007-2014, at the 8 fixed monitoring stations located throughout the city, mean annual concentration of nitrogen dioxide was in the range $0.03-0.06 \mathrm{mg} / \mathrm{m} 3$, nitrogen oxide $-0,04-1,4 \mathrm{mg} / \mathrm{m} 3$, carbon oxidative $0.03-1,4 \mathrm{mg} / \mathrm{m} 3$, sulfur dioxide $0,004-1,3 \mathrm{mg} / \mathrm{m} 3$. Concentrations of formaldehyde were detected in the range $0.009-0.013 \mathrm{mg} / \mathrm{m} 3$ Phenol $-0.002 \mathrm{mg} / \mathrm{m} 3$, suspended solids - 0,04$0,16 \mathrm{mg} / \mathrm{m} 3$, hydrogen sulfide $-0.001 \mathrm{mg} / \mathrm{m} 3$, hydrochloride $-0.08 \mathrm{mg} / \mathrm{m} 3$.

The biggest number of samples exceeding 1 maximum allowable concentration was identified in terms of formaldehyde (2.3\%), sulfur dioxide and carbon monoxide (respectively 0.92 and $0.67 \%$ ). The number of samples in which the substance concentrations exceeded 2 and 3 MAC was insignificant - less than $0,01 \%$. At the same time, the level of air pollution in Penza is viewed as high: the air pollution index in 2007-2014 totaled 10-11 which placed Penza into the group of "risk" areas in terms of air pollution indicator. Exposure to hazardous substances that exceeds the hygienic standards concerns the population of 500 thousand residents including 84 thous. children and teenagers. It was revealed that the calculated individual life-long carcinogenic risk from formaldehyde equals $0,3 * 10^{-6}$ which is considered allowable and perceived by everyone as negligibly small, not different from the regular everyday risks. Such risk does not require any additional mitigation actions; however the level of risk should be monitored regularly.

Individual lifelong carcinogenic risk from exposure to lead in the atmospheric air was registered at $0,5^{*} 10^{-5}$, which corresponds to the maximum allowable level of risk meaning the highest level of acceptable risk. These levels are subject to regular inspection. In some cases, additional mitigation activities might be needed at this level of risk. Overall, total carcinogenic risk for the inhalation route of entry corresponds with the maximum allowable risk and is subject to regular control.

In Penza with the population of 520 thous. people, population carcinogenic risk from formaldehyde in atmospheric air totals 0.02 additional cases of cancer annually, from inhalation exposure to lead3.7 additional cases of malignant growths per year.

Assessment of the risk of non-cancer illnesses in children and teenagers living in Penza showed that there is a probability of harmful effects resulting from daily intake of pollutants from atmospheric air. The biggest contributors to that risk are lead and its compounds, formaldehyde, dusts, nitrogen, and dioxide (table 1).

The risk of non-cancer effects is registered in 9 organs and systems (targets) including respiratory organs, central nervous system, hemic system, reproductive and hormonal systems, kidney, cardiovascular system, eyes, and immune system. Under combined exposure, the biggest toxicological load affects respiratory organs $(\mathrm{HI}=6,65)$, organs of vision and the immune system $(\mathrm{HI}=3,28)$ (Table 2).

The ranging of the chemical substances in terms of hazard quotient allowed identifying the leading air pollutants: lead, suspended substances, and sulfur dioxide. The calculation of the hazard quotients by individual pollutants allowed identifying the share of each of the substances in the total hazard index: lead $-37 \%$, suspended substances$25 \%$, sulfur dioxide $-18 \%$.

The substances that defined carcinogenic risk during the consumption of drinking water included, first of all, cadmium and lead. Individual carcinogenic risk from exposure to cadmium equals $0.9^{*} 10^{-5}$ and falls under the second range corresponding with the maximum permissible level of risk. Population carcinogenic risk from 
Factors and indicators of non-cancer inhalation risk in children living in Penza

\begin{tabular}{|l|c|c|c|c|}
\hline \multicolumn{1}{|c|}{ Substance } & dose, $\mathrm{mg} / \mathrm{kg}$ & RfC, $\mathrm{mg} / \mathrm{kg}$ & HQ & Affected organ, system \\
\hline Lead & 0,002 & 0,0005 & 4,00 & $\begin{array}{c}\text { Central nervous system, blood, reproductive system, hormonal } \\
\text { system, kidneys }\end{array}$ \\
\hline Formaldehyde & 0,01 & 0,003 & 3,28 & Respiratory organs, eyes, immune system \\
\hline Suspended solids & 0,17 & 0,075 & 2,06 & Respiratory organs \\
\hline Mitrogen dioxide & 0,043 & 0,04 & 1,17 & Respiratory organs \\
\hline Carbon oxide & 1,12 & 3 & 0,38 & Cardiovascular system \\
\hline Sulphur dioxide & 0,006 & 0,05 & 0,14 & Respiratory organs \\
\hline
\end{tabular}

Table 2

The risk of negative inhalation effects on the critical organs and systems in children in Penza

\begin{tabular}{|l|c|c|}
\hline \multicolumn{1}{|c|}{ Affected organs and systems } & Hazard index & Leading risk factors \\
\hline Respiratory organs & 6,65 & Formaldehyde, suspended substances, nitrogen dioxide \\
\hline Blood & 4,00 & Lead \\
\hline Central nervous system & 4,00 & Lead \\
\hline Cardiovascular system & 0,38 & carbon monoxide \\
\hline Immune system & 3,28 & Formaldehyde \\
\hline Eyes & 3,28 & Formaldehyde \\
\hline Reproductive system & 4,00 & Lead \\
\hline Hormonal system & 4,00 & Lead \\
\hline kidneys & 4,00 & Lead \\
\hline
\end{tabular}

exposure to cadmium in polluted water equals 12.4. Individual carcinogenic risk from exposure to lead in drinking water equals $0.8^{*} 10^{-5}$ and also falls under the second range. Population carcinogenic risk from exposure to lead in polluted water equals 11. Population carcinogenic risk per annum from exposure to lead in polluted water equals 0.16 . Total carcinogenic risk for the peroral route of entry equals $1.7^{*} 10^{-5}$ and falls under the second range of risk corresponding to the maximum permissible level of risk, that is the highest value of acceptable risk.

Drinking water from Sura water basin used by Penza residents most times does not meet the hygienic standards in terms of the level of iron, turbidity, color, permanganate oxygen consumed; in some cases, the levels of residual chlorine and chloroform exceeded the standard values. The analysis of available data on the drinking water from Penza water supply system reveals concerns regarding susceptibility of the residents to chlororganic compounds detected in water, chloroform, trichloromethane and the formation of trihalomethanes. It was revealed that drinking water carries a relatively high risk of carcinogenic risk due to the impact of tetrachloroethylene and chloroform, first of all. The level of this risk is 1.6 times higher in Penza as compared to Zarya micro-district that draws water from the underground sources. In Penza, the share of drinking water in carcinogenic risk equals $19 \%$.
Non-cancer risk causes increased levels of nitrates and a number of heavy metal compounds in drinking water (Table 3). Hazard quotient was registered at higher than one for nitrate, cadmium, lead and iron, etc. Despite the fact that other substances do not exceed the threshold value of the hazard quotient, they need to be analyzed in the aggregate.

As a result of the assessment of non-cancer risks, we obtained the values of hazard quotient presented in Table 4. Impermissible risk of noncancer effects is registered in 10 organs and systems (targets): blood system, humoral and immune system, kidney, central nervous system, nervous system, mucous membranes and skin, cardiovascular system, and gastrointestinal tract. The highest risks are registered in the blood, hormonal system, kidney, and central nervous system.

According to the data for 2007-2014, the concentration of chemical pollutants in soil inclusive of the regional background levels is decreasing. The analysis of the concentration of heavy metals in the soil revealed exceeding background levels calculated for Penza region in general: lead - by 1.1-5.3 times, cadmium - 1.4-6.7 times, zinc - by 1.2-2.5 times. The highest values of the concentration of heavy metals were registered in the areas adjacent to the city highways. According to the studies, the concentration of salts of heavy metals in the soil samples does not exceed maximum permissible concentration. 
Table 3

Factors and indicators of non-cancer risk associated with drinking water for child health in Penza

\begin{tabular}{|l|c|c|c|c|}
\hline \multicolumn{1}{|c|}{ Substance } & Dose, $\mathrm{mg} / \mathrm{kg}$ & $\mathrm{RfD}, \mathrm{mg} / \mathrm{kg}$ & $\mathrm{HQ}$ & Affected organs and systems \\
\hline Nitrite & 0,24 & 0,1 & 2,4 & Blood \\
\hline Cadmium & 0,0009 & 0,0005 & 1,8 & Kidney, hormonal system \\
\hline Lead & 0,006 & 0,0035 & 1,7 & Central nervous system, hormonal system \\
\hline Iron & 0,37 & 0,3 & 1,2 & Mucous, blood, skin, the immune system \\
\hline Molybdenum & 0,0025 & 0,0025 & 1,0 & Kidney \\
\hline Mitrates & 1,49 & 1,6 & 0,9 & The blood, cardiovascular system \\
\hline Manganese & 0,08 & 0,14 & 0,6 & The central nervous system, the blood \\
\hline Copper & 0,01 & 0,019 & 0,5 & Gastrointestinal tract \\
\hline Aluminum & 0,26 & 1 & 0,26 & The central nervous system, the blood \\
\hline
\end{tabular}

Table 4

The risks of negative peroral impact on the critical organs and systems of Penza children

\begin{tabular}{|l|c|c|}
\hline \multicolumn{1}{|c|}{ Affected organ, system } & Hazard index & Leading risk factor \\
\hline Blood & 3,90 & Nitrites, iron compounds, nitrates \\
\hline Hormonal system & 3,50 & Cadmium, Lead \\
\hline kidneys & 2,80 & Cadmium, molybdenum \\
\hline central nervous system & 2,56 & Lead, manganese \\
\hline Nervous system & 1,70 & Lead, aluminum \\
\hline mucous & 1,24 & Iron compounds \\
\hline Leather & 1,20 & Iron compounds \\
\hline The immune system & 1,20 & Iron compounds \\
\hline Cardiovascular system & 0,90 & Nitrates \\
\hline Gastrointestinal tract & 0,50 & Copper compounds \\
\hline
\end{tabular}

The safety of food consumed by children and teenagers was assessed in terms of the main food groups by analyzing the content of the following contaminants: cadmium, arsenic, lead, nitrates, pesticides, mycotoxins

A socio-hygienic monitoring of the safety of food products showed that in 2007-2014, there were isolated cases of exceeding hygienic standards in terms of the contents of cadmium (from 0,06 to $0,4 \%$ ), pesticides $(0,5-0,6 \%)$ and nitrates $(0,2-2,1 \%)$, mycotoxins $(0,7-0,78 \%)$. Individual carcinogenic risk from peroral route of entry with food products of single cadmium, lead, and arsenic at the median rates was at the allowable level: for cadmium - at the level $2.2 \times 10^{-5}$, lead $-7.9 \times 10^{-5}$, arsenic $-1.8 \times 10^{-4}$. The average daily child intake of sodium nitrate totaled $0.23 \mathrm{mg} / \mathrm{kg}$, sodium nitrite $-0,11 \times 10^{-4} \mathrm{mg} / \mathrm{kg}$, hexachlorocyclohexanes - $0,13 \times 10^{-5} \mathrm{mg} / \mathrm{kg}$, dichloro-diphenyl-trichloroethane $-0,16 \times 10^{-4} \mathrm{mg} / \mathrm{kg}$, mycotoxin $-0,01 \times 10^{-5} \mathrm{mg} / \mathrm{kg}$.

Non-cancer risk for the child health calculated at the level of median content of contaminants in in food products did not exceed 1.0. At $90^{\text {th }}$ percentile, non-cancer HQ associated with the cadmium content in food products in 2014 totaled 1.5, lead content - 2.4. The allowable level of non-cancer risk was also exceeded in terms of the content of arsenic in the food products $(\mathrm{HQ}=3.1)$, nitrates 2.4 и nitrites -1.8 .

The revealed exceedance of the allowable level of non-cancer risk indicates possible health disorders in children affecting the cardiovascular system, central nervous system, hormonal, hematopoietic system, immune system, skin and digestive tract.

Calculations of the non-cancer risk revealed that biggest contributors to the overall exposure are bread and bread products (30\%), vegetables and melons (21\%), milk and dairy (13\%). Cadmium exposure is also presented by bread and bread products $-37 \%$, vegetables and melons $-19 \%$ and potatoes $-18 \%$. The biggest carriers of arsenic exposure are fish and fish products $-43 \%$, bread and bread products - 18\%, vegetables and melons $-14 \%$. Potatoes, vegetables and melons roughly equally (51 and 49\%) carry exposure to nitrates The conducted calculated of the negative risks associated with the contaminants in food products indicate the need for a regular food safety monitoring at the regional level.

Based on the conducted calculations, the following conclusions were made:

- The current total cancer risk from inhalation or peroral intake of the major toxic agents and contaminants with food products by the children and teenagers residing in Penza corresponds with the 
maximum allowable level and does not require reduction measures; however regular control is recommended;

- The biggest non-cancer risk associated with air pollution exists in regards to the respiratory organs, organs of vision, and the immune system. Impermissible inhalation hazard that affects the health of children and teenagers in Penza is created by the presence in the environment of lead compounds as well as formaldehyde and nitrogen dioxide.

- The chemical content of drinking water brings about impermissible risks resulting in the disorders of the following systems: blood, hormonal, kidney; and the contaminants consumed with food products bring about the risks that can cause disorders of the hematopoietic system and the cardiovascular system;

- The non-cancer risk to child health calculated at the level of the median content of contaminants in food products does not exceed the permissible level.

The health risk method used to study the impact of the chemical contaminants in the environment on child population can help validate the preventative measures aimed to reduce the risks to child and teenage health. One such a measure is to expand the monitoring studies of the environmental pollution to identify the high risk areas that present hazard to the health of the child population; to promote the ecological and environmental.

\section{References}

1. Gorshkov A.I., Cherkasova L.V., Osipova E.M. Kompleksnaja gigienicheskaja ocenka okruzhajushhej sredy i zdorov'ja detej v Severnom administrativnom okruge Moskvy // Complex hygienic assessment of the environment and child health in the North Administrative District of Moscow // Gigiena i sanitarija. - 2012. - №2. - Pp. 77- 79.

2. Zaitseva N.V., Shur P.Z., Kiriyanov D.A. Analiz upravljaemyh faktorov riska neinfekcionnoj patologii v Permskom krae // Analysis of the controlled factors of non-infectious pathology risk in Perm Krai // Uralskiy medicinskij zhurnal. - 2013. - №2. - Pp. 14-26.

3. May I.V., Zaitseva N.V., Klein S.V., Sedusova E.V. // Ustanovlenie i dokazatelstva vreda zdorov'ju grazhdanina, nanosimogo negativnym vozdejstviem faktorov sredy obitanija // Proof and evidence of health effects associated with the negative impact of the environment // Zdorovie naseleniya i sreda obitaniya. - 2013. - № 11 - Pp. 4-6.

4. Mizina N.G. Gigienicheskaja ocenka riska dlja zdorov'ja detskogo naselenija pri vozdejstvii tjazhelyh metallov, zagrjaznjajushhih okruzhajushhuju sredu. Hygienic assessment of the risk to child health created by the impact of the heavy metals polluting the environment. Synopsis of a thesis ... Candidate of Medical Sciences. - Kemerovo, 2012.

5. Minenko E.Ju., Kuramshin D.Yu. Vozdejstvie avtomobil'nogo transporta na okruzhajushhuju sredu i zdorov'e naselenija Penzy // Environmental and health risks associated with the motor vehicles // Internet-Vestnik VolgGASU. 2014. № 3 (34). P. 22.

6. The sanitary and epidemiological well-being of the RF population in 2014: State report. - M: Federal Service for the Inspection of Consumer Rights Protection and Human Wellbeing 2015 - 206 p.

7. Onischenko G.G. The concept of risk in socio-hygienic monitoring (issues and solutions) / Koncepciya riska i eyo mesto $v$ sisteme socialno-gigienicheskogo monitoringa (problemy i puti reshenija) Digest of the Russian Academy of Medical Sciences. 2005. № 11. P. 27-33

8. Popova A.Ju. Strategicheskie prioritety Rossijskoj Federacii v oblasti jekologii s pozicii sohranenija zdoroviya nacii // The RF strategic priorities in preserving the environment in terms of public health. $\mathrm{ZN} \mathrm{i} S \mathrm{SO}$. 2014. - №2. - P. 4-profilakticheskoj mediciny // Gigiena i sanitariya. - 2014. - №5. - P. 5-10.

9. Rakhmanin Yu.A., Zaitseva N.V., Shur P.Z., Novikov S.M., May I.V., Kiriyanov D.A., Kobyakova O.A. Nauchno-metodicheskie i jekonomicheskie aspekty reshenija regional'nyh problem $\mathrm{v}$ oblasti mediciny okruzhajushhej sredy // Research and economical aspects of the regional issues in the sphere of environmental medicine // Gigiena i sanitariya // 2005. № 6. P. 6.

10. Rakhmanin Yu.A., Mikhailova R.N. Okruzhayuschaya sreda i zdorovie: prioritety // Environment and public health: priorities // Gigiena i sanitariya. - 2014. - №5. - P. 5-10.

11. Ryzhakov S.A., Zaitseva N.V., May I.V., Alekseyev V.B., Podluzhnaya M.Ya., Kiriyanov D.A. Makrojekonomicheskiy analiz poter zdoroviya, verojatnostno obuslovlennyh emissiyami zagryaznyayuschikh veshhestv $\mathrm{v}$ atmosferniy vozduh // Macroeconomic analysis of health losses possibly resulting from the emission of pollutants in the atmospheric air // Permskiy medicinskij zhurnal. 2009. 26. № 3. P. 139-143.

12. Environmental Health Risk Assessment. Guidelines for assessing human health risks from environmental hazards / Commonwealth of Australia, 2004. Department of Health and Ageing and Health Council. Commonwealth of Australia, 2004. - 258 p.

13. Kolluru R.V. Health Risk Assessment Text: Principles and Practices // Risk Assessment and Management handbook. For Environmental, Health, and Safety Professionals. New York, 1996. P. 123

14. McClellan R.O. Human health risk assessment: a historical overview and alternative paths forward // Inhalation Toxicology. 1999. № 11(6-7). P. 477-518.

15. WHO, 1999. Principles For The Assessment Of Risks To Human Health From Exposure To Chemicals: Environmental Health Criteria 210 / WHO. - 1999. 